\title{
Comparative Performance of Machine for Crop Residue Management in Rice-Wheat Cropping System
}

\author{
Sourabh Kumar Dewangan ${ }^{1 *}$, R. K. Naik ${ }^{2}$ and Pushpraj Diwan ${ }^{1}$ \\ ${ }^{1}(F M P E), S V C A E T \& R S, I G K V$, Raipur (C.G.), India \\ ${ }^{2}$ (FMPE), PI-AICRP-FIM, SVCAET \& RS, IGKV, Raipur (C.G.), India \\ *Corresponding author
}

\begin{tabular}{l} 
Ke y w o r d s \\
Cultivated cereal \\
crops, \\
Rice wheat, \\
Rotary mulcher \\
\hline Article Info \\
\hline $\begin{array}{l}\text { Accepted: } \\
\text { 26 April } 2020 \\
\text { Available Online: } \\
\text { 10 May } 2020\end{array}$ \\
\hline
\end{tabular}

\section{Introduction}

Rice-wheat cropping system is very common in India, Pakistan, Bangladesh and Nepal and this cropping system contributes $70 \%$ of total food grain production with an area covered is $12 \mathrm{M}$ ha in India. But, it is estimated that under rice and wheat crop separately, the area covered is 42.31 and $22.98 \mathrm{M}$ ha respectively (Chauhan, 2016). Crop residues are parts of the plants which are leftover the field after crops have been harvested by a combine harvester. Crop residues burn in India due to which the environment polluted and soil fertility also decrease.

Though in many countries the crop residues are used as a source of energy in different way viz. livestock feed, mushroom cultivation, compost making, bio-fuel, bio-oil production, gasification, bio-char production etc. 


\section{Materials and Methods}

\section{Experimental site}

The experiment was conducted in Rabi season at Research Farm, Indira Gandhi KrishiVishwaVidyalaya, Raipur (C.G.)at $21^{\circ} 23$ '54" North latitude and $81^{0} 69^{\prime} 56^{\prime \prime}$ "East longitude with an altitude of 268.99 meter above mean sea level on paddy crop residue on combine harvested paddy field.

\section{Design of experiment}

In the experiment, for crop residue management in rice wheat cropping system various farm machines were used viz zero till happy seeder $\left(T_{1}\right)$, mulcher + zero till drill $\left(\mathrm{T}_{2}\right)$, zero till drill $\left(\mathrm{T}_{3}\right)$ and conventional system for wheat cropping.

In these experiment machine parameter (operation speed, a slip of tractor, effective field capacity and fuel consumption), soil parameter (moisture content, bulk density and nutrient content of soil), residue parameter (length, weight and moisture content of residue/straw), plant parameter (height of plant, population of plant, length of ear head, grain weight, straw grain-ratio), energy analysis and cost analysis was done.

\section{Machine parameter}

\section{Slip of tractor}

Tire slip occurs when the tires are turning faster than the ground speed of the tractor. Due to slip the power of a tractor engine develops is used to pull an implement through the soil. The conventional method of measuring tractor drive-wheel slip consists of measuring the base (unloaded) distance for a given number of drive wheel revolutions and then measuring the loaded distance for the same number of wheel revolutions.
Percent slip is given by the relation (Zoerb and Popoff, 1967):

Per centslip $(\%)=\frac{100(B-L)}{B}$

Where,

$\mathrm{B}=$ Base distance, $\mathrm{m}$;

$\mathrm{L}=$ Loaded distance, $\mathrm{m}$.

\section{Effective field capacity}

Effective field capacity (EFC) of a farm machine is calculated by dividing the area ended or completed by the hour of actual time.

$\mathrm{EFC}=\frac{\mathrm{WS}}{10} \times n$

Where,

$\mathrm{EFC}=$ Effective field capacity of the machine, ha/h;

$\mathrm{W}=$ Width of the machine, $\mathrm{m}$;

$\mathrm{S}=$ Speed of the machine, $\mathrm{km} / \mathrm{h}$; and

$n=$ Efficiency of the machine, percentile.

\section{Fuel consumption}

Fuel consumption (FC) was determined by top-up method. The fuel tank was filled full level before the operation. After one hour of work, it was again filling up to top level. The quantity of fuel top-up was measured by a measuring cylinder.

$$
\text { FC }(\text { lit } / \mathrm{h})=\frac{\text { Consuption of fuel }\left(\frac{\text { lit }}{\mathrm{h}}\right)}{\text { Coverd area }\left(\frac{\mathrm{ha}}{\mathrm{h}}\right)}
$$

\section{Moisture content of the soil}

In experiment, three times irrigation was applied and after each irrigation moisture content of the soil was measured. 
The moisture content of the soil is calculated after every week until the next irrigation. Oven drying method was used for soil moisture analysis. Soil sample are taken in the oven at $105^{\circ} \mathrm{C}$. After 24 hours dry soil sample weight was measured and moisture content of soil was determined by using following relation:

$\mathrm{mc}, \%($ dry basis $)=\frac{W 2-W 3}{W 3-W 1} \times 100$

Where, $\mathrm{mc}=$ Moisture content;

$\mathrm{W}_{1}=$ weight of container;

$\mathrm{W}_{2}=$ weight of the container and wet soil:

$\mathrm{W}_{3}=$ weight of the container and oven-dry soil.

\section{Crop parameter}

\section{Grain weight}

After harvesting of crop 1000 grain was selected manually and weighed by using of electronic balance from each plots.

\section{Straw-grain ratio}

Straw grain ratio (SRG) was fiend by dividing of the weight of straw and weight of total grain.

$\mathrm{SRG}=\frac{\mathrm{Ws}}{\mathrm{Wg}}$

Where, $\mathrm{W}_{\mathrm{s}}=$ weight of straw; and

$\mathrm{W}_{\mathrm{g}}=$ weight of grain

\section{Energy and cost analysis}

Energy required for wheat crop was measured as source and operation wise in which inputoutput energy ratio and other energy calculation was measured for experiment (Jat et al., 2015). The operation cost was calculated in two way fixed cost and operation cast. In operation cast include
Lubricants, fuel, Repair- maintenance and wages (Fig. 1-3).

\section{Results and Discussion}

\section{Machine parameter}

\section{Slip of tractor}

Slip of tractor in happy seed drill, rotary mulcher, zero till and cultivator was observed $1.5,-1.2,1.8$ and 1.5, respectively. Rotary mulcher measured negative slip (Table 2).

\section{Effective field capacity}

It was found that maximum field capacity was recorded in $\mathrm{T}_{3}$ followed by $\mathrm{T}_{1}$. Lowest EFC was observed in the case of $\mathrm{T}_{2}$ and $\mathrm{T}_{4}$ due to the combination of two to three operations imposed in the same field, which was given in Table 1.

\section{Fuel consumption}

Minimum fuel consumption was found in $T_{3}$ treatment, zero till seed drill while maximum fuel consumption was obtained for $T_{2}$ treatment, rotary mulcher + zero till drill.

\section{Soil parameter}

Observing moisture content was higher in $\mathrm{T}_{1}$ treatment and lower in $\mathrm{T}_{4}$ treatment before second irrigation. A similar observation was done in the moisture content of soil for other irrigation. After 18 week save rage moisture content of the soil at $\mathrm{T}_{1}, \mathrm{~T}_{2} \mathrm{~T}_{3}$ and $\mathrm{T}_{4}$ treatment were observed 14, 12, 11 and 10\%, respectively (Table 3 ).

\section{Crop parameter}

Straw grain ratio 1.35 was measured higher in $\mathrm{T}_{4}$ treatment while 1000 grain weight $49.9 \mathrm{~g}$ was measured higher in $\mathrm{T}_{2}$ treatment (Table 4). 
Table.1 Experiment Detail

\begin{tabular}{|l|l|l|}
\hline S. No. & Particulars & Specification \\
\hline $\mathbf{1 .}$ & Number of Treatment & 4 \\
\hline 2. & Number of replications & 5 \\
\hline 3. & Net Plot size & $62 \mathrm{~m} \mathrm{X} \mathrm{22.5} \mathrm{m}$ \\
\hline $\mathbf{4 .}$ & Total no. of plot & 20 \\
\hline $\mathbf{5 .}$ & Distance between replications & $0.5 \mathrm{~m}$ \\
\hline 6. & Distance between plots & $0.5 \mathrm{~m}$ \\
\hline $\mathbf{7 .}$ & Last crop harvested & Paddy \\
\hline $\mathbf{8 .}$ & Soil type & Vertisol \\
\hline $\mathbf{9 .}$ & Sowing crop & Wheat \\
\hline $\mathbf{1 0 .}$ & Varity & GW-366 \\
\hline $\mathbf{1 1}$. & Date of sowing & 15.11 .2018 \\
\hline $\mathbf{1 2}$. & Date of harvesting & 27.03 .2019 \\
\hline & & \\
\hline
\end{tabular}

Table.2 Average Machine parameter

\begin{tabular}{|c|c|c|c|}
\hline Treatments & Slip (\%) & $\begin{array}{c}\text { Effective ield } \\
\text { capacity }\end{array}$ & Fuel consumption \\
\hline $\mathbf{T}_{\mathbf{1}}$ & 1.5 & 0.251 & 4.5 \\
\hline $\mathbf{T}_{\mathbf{2}}$ & -1.2 & 0.33 & 2.9 \\
\hline $\mathbf{T}_{\mathbf{3}}$ & 1.8 & 0.34 & 2.96 \\
\hline $\mathbf{T}_{\mathbf{4}}$ & 1.5 & 0.310 & 6.4 \\
\hline
\end{tabular}

Table.3 Average moisture content of soil under different treatments

\begin{tabular}{|l|l|l|l|l|l|l|l|l|l|l|l|l|l|l|l|l|l|l|}
\hline Treatments & \multicolumn{11}{|c|}{ Weeks } \\
\hline & 1 & 2 & 3 & 4 & 5 & 6 & 7 & 8 & 9 & 10 & 11 & 12 & 13 & 14 & 15 & 16 & 17 & 18 \\
\hline $\mathrm{T}_{1}$ & 39 & 34 & 28 & 21 & 37 & 33 & 27 & 20 & 34 & 31 & 25 & 19 & 31 & 23 & 21 & 19 & 17 & 14 \\
\hline $\mathrm{T}_{2}$ & 39 & 32 & 27 & 20 & 36 & 32 & 28 & 20 & 33 & 29 & 23 & 18 & 32 & 20 & 19 & 17 & 14 & 12 \\
\hline $\mathrm{T}_{3}$ & 39 & 30 & 25 & 17 & 32 & 26 & 21 & 19 & 30 & 24 & 19 & 17 & 28 & 23 & 17 & 16 & 13 & 11 \\
\hline $\mathrm{T}_{4}$ & 39 & 29 & 21 & 16 & 30 & 26 & 23 & 18 & 29 & 23 & 20 & 17 & 27 & 23 & 18 & 15 & 12 & 10 \\
\hline
\end{tabular}


Table.4 Average straw-grain ratio and Grain weight of wheat crop in various treatments

\begin{tabular}{|c|c|c|}
\hline Treatment & Straw-grain ratio & 1000 Grain weight $(\mathbf{g})$ \\
\hline $\mathbf{T}_{\mathbf{1}}$ & 1.31 & 49.24 \\
\hline $\mathbf{T}_{\mathbf{2}}$ & 1.308 & 49.9 \\
\hline $\mathbf{T}_{\mathbf{3}}$ & 1.30 & 48.68 \\
\hline $\mathbf{T}_{\mathbf{4}}$ & 1.35 & 49.7 \\
\hline
\end{tabular}

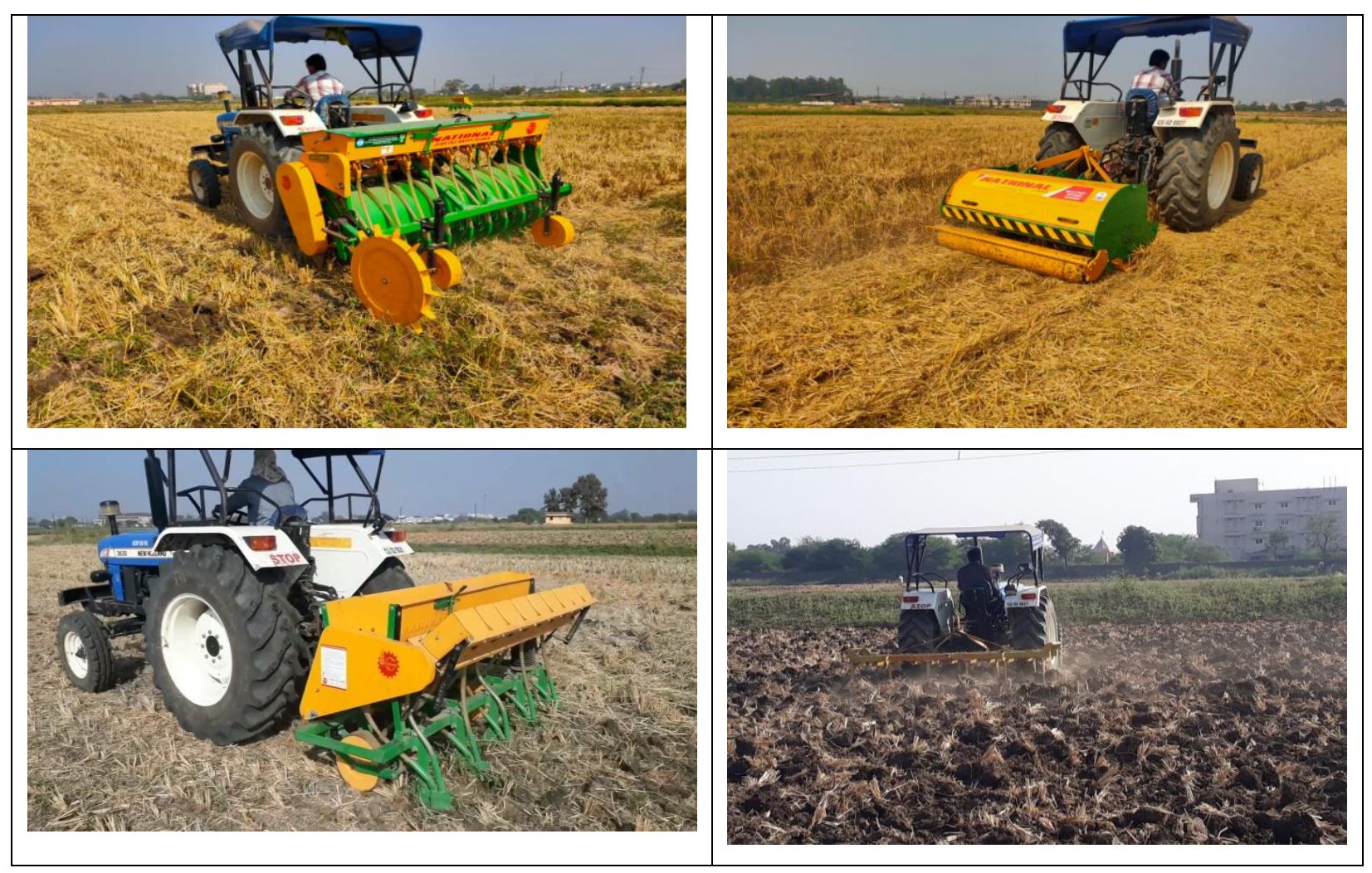

Fig.1 Machine performance for different treatment

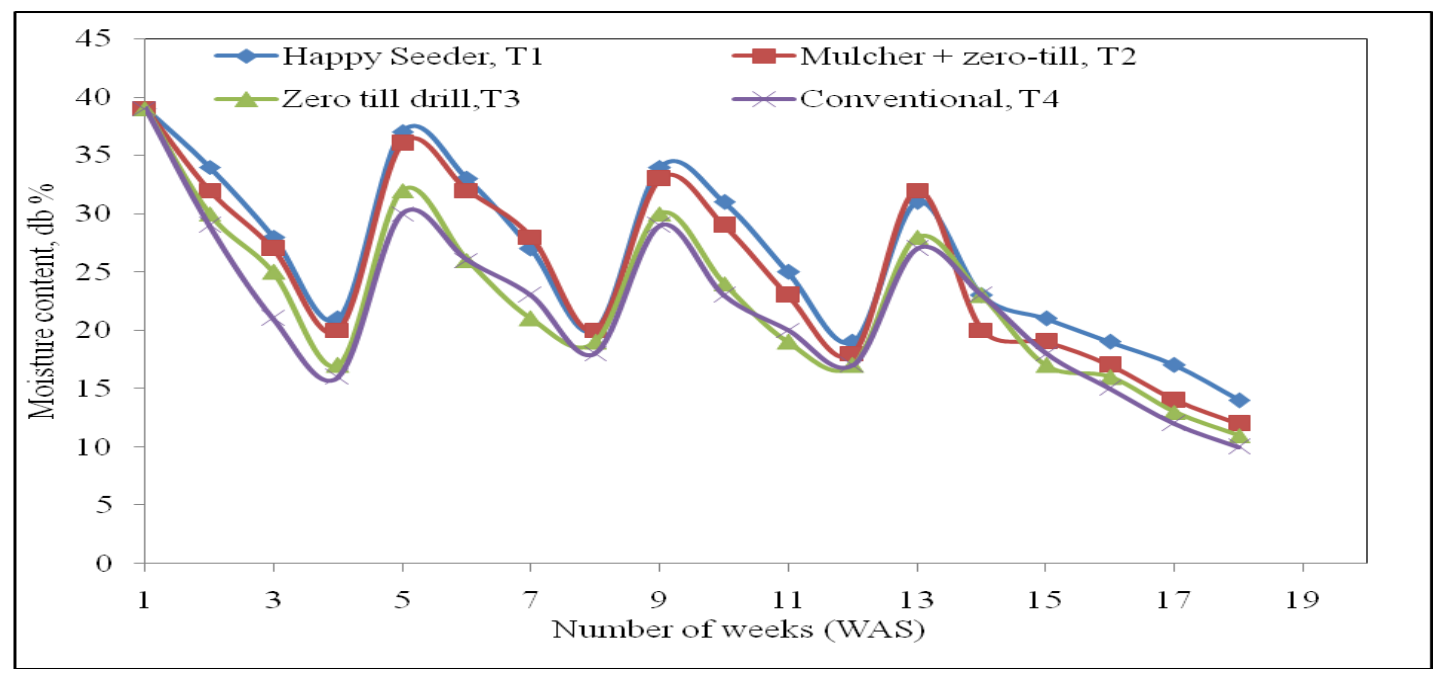

Fig.2 Moisture content of soil of various treatments 


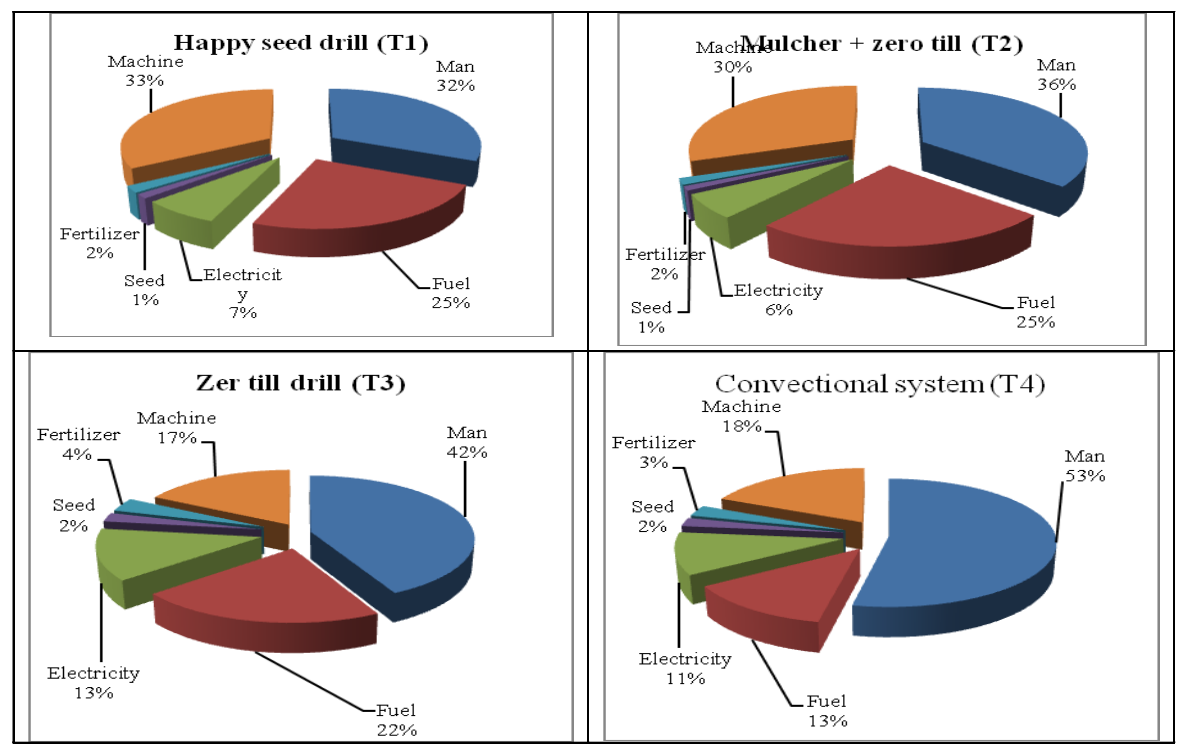

Fig.3 Energy requirement of various treatments for different sources

\section{Energy and cost analysis}

In this experiment energy required in $\mathrm{T}_{1}, \mathrm{~T}_{2}$, $\mathrm{T}_{3}$ and $\mathrm{T}_{4}$ treatments are 4120.74, 5013.85, 2191.29 and 5214.11 $\mathrm{MJ} / \mathrm{ha}$, respectively. Minimum energy requirement observed in T3 treatment because there is no tillage done. In this experiment cost required in $\mathrm{T}_{1}, \mathrm{~T}_{2}, \mathrm{~T}_{3}$ and $\mathrm{T}_{4}$ are 2228.13, 2297.72, 1025.85 and 2452 ₹ /ha, respectively. In $\mathrm{T}_{3}$ treatment observed lower cost requirement because there is notillage work done and labor work are minimum.

\section{References}

Chauhan, J. S. 2016. Tillage and sowing methods for cultivation of wheat in vertisol. M.Sc. Thesis, JNKVV, Jabalpur. 114.

Jat, D., Naik, R. K., Khandelwal, N. K., Patel, B. and Shrivastva, P. 2015. Land holding effect on energy inputs for soybean production in Malwa plateau of Madhya Pradesh. American International Journal of Research in Science Technology, Engineering and Mathematics, 9(3): 269-274.

Sonwani, S. 2018. Residue management through tillage practice in combine harvested rice field, M. Tech Thisis . Indira Gandhi KrishiVishwavidyalaya, Raipur, 1-92.

Sonwani,S., Quasim,M., Verma, A, and Diwan, P. 2019. Incorporation of Residue into the Soil in Combine Harvested Paddy Field by Machineries Combination.Int.J.Curr.Microbiol.App. Sci, 8(11): 1384-1391.

Zoerab, G. C. and Popoff, J. 1967. Direct indication of tractor-wheel slip. Canadian Agricultural Engineering, 9: 91-108.

\section{How to cite this article:}

Sourabh Kumar Dewangan, R. K. Naik and Pushpraj Diwan. 2020. Comparative Performance of Machine for Crop Residue Management in Rice-Wheat Cropping System. Int.J.Curr.Microbiol.App.Sci. 9(05): 3284-3289. doi: https://doi.org/10.20546/ijcmas.2020.905.389 